\title{
Internationalization of Universities Myth \& Realities: A Case Study of COMSATS Institute of Information Technology (CIIT) Pakistan
}

\author{
Shahid Iqbal \\ COMSATS Institute of Information Technology (CIIT), Quality Enhancement Cell, Park Road, Tarlai Kalan Post Code 45550, \\ Islamabad Pakistan
}

Copyright (C) 2015 Horizon Research Publishing All rights reserved.

\begin{abstract}
This study was based to assess trend of Pakistani universities towards internalization as compared to the successful models of USA, UK, Australia and Canada with particular efforts being made by COMSATS Institute of Information Technology, Pakistan. The primary data of Pakistani universities, views and ideas of researchers were discussed and analysis about the realities to utilize the treasures of "knowledge based economic" opportunities. All such efforts were resulted due to reduction of government funds for the universities. The parameters of discussion and analysis were based on data collection from prominent Pakistani Universities as a primary source while secondary source was research based wherein researchers' experiences quoted and shared to assess the myth and realities for internationalization of international universities in certain regions of the world. The major findings were focused towards the induction of international students' success stories in universities of USA, UK, Canada, Australia and Malaysia. The universities of these countries earned profit and reduced the dependence government funds and achieved economic self-reliance breakthrough based on recruitment of International students in the past two decades. In south East Asia the Malaysian Universities has adopted these role models of successful countries and is now on the top position for recruiting international students. In Pakistani universities this trend is also flourishing very rapidly. The comparison of CIIT with other Pakistani universities especially in the area of international students' recruitment indicates that the International Islamic university (IIU) was at the top in Pakistan. It was concluded that CIIT Pakistan is moving on faster track towards internationalization of its academic and research programs and as a policy allocated huge number of scholarships for international students and also attained international ranking of QS 3 stars out of 5 in general terms and 5 out of 5 in academic, outreach and civic engagements and placed among 250 QS Top Asian Universities and at 4rth position in Pakistani general universities in view of national ranking of higher education commission in the year 2013. The other Pakistani universities have also excelled in
\end{abstract}

research and academics and created ample environment for cross cultural adaptations and also moving towards internationalization like CIIT Pakistan.

Keywords Internationalization of Universities, Trend in Pakistan, Students Recruitment, Ranking, Corporatization

\section{Introduction}

The International universities in USA, UK, Australia and Canada have played an important role for stabilized funding resources through utilization of knowledge based economic systems and emerged as major international students induction players in the world in the last two decades. This was achieved as a result of shortfall occurred in government funding and such universities of higher learning were diverted towards corporatization. Monk [1] discussed the deregulations aspects undertaken in South East Asia like China where universities structures and other essential modalities were changed for universities corporatization. Talik [3] and Elkin [4] also emphasized the deregulations and remolding of the university's academic programmes towards internationalization and finding new sources of knowledge economy. The universities all over the world and especially in Asian region become more competitive and undertaken various incredible changes in their infrastructure, academic methodologies, research initiatives including collaborative research in the way of International Ranking \& acceptance by the international community.

In the Asian sub-continent, Pakistani universities both in public and private sector institutions the quality of higher education services were increased manifold during the last decade and inclined towards knowledge based economic systems. As per indicators mentioned in the Annual Report [10], some of Pakistani universities made efforts for internationalization of their research and academic programs and also provided enhanced facilities to induct International 
Students like International Islamic University and CIIT Pakistan. As per Annual Report [12] CIIT Pakistan has speeded up their marketing efforts internationally and gone into certain mutual collaborative agreements for students/teachers exchange programs, collaborative research and projects joint ventures and to induct more international students in their systems in spite of various ethnic and terrorism fears in the region and in Pakistan.

CIIT ranked in top 250 QS Asian International Universities with QS 3 star ranking in general and 5 star in academics and outreach civic engagements. In Pakistan universities are now on the track of internationalization and inspired from role models of world universities of USA, UK and Australia. In south East Asia, Malaysian universities are playing important role and attracting /inducting huge number of international students.

\section{Objectives}

The prime objective of this research was based on to assess CIIT Pakistan with other universities and to familiarize and discuss international role models international world universities, the trend of other Pakistani universities towards internationalization. Pace of International students' recruitment by exploring the knowledge based economic role models to fulfill the gaps of substantive government funding in universities and to set needs for detailed research in the relevant areas for Pakistani universities and CIIT Pakistan.

\section{Methodology}

Observation: A wider web based survey was conducted for investigating the websites of Pakistani and International universities internationalizing their academic programme and recruits international students for profit earning. Primary and Secondary research has been carried out to investigate the previous related work done by the researcher worldwide.

Questionnaire Survey: A questionnaire was designed and developed to fulfill the objectives of this study and provided online to respondents (Registrar's of the Pakistani Universities). This questionnaire was comprised of following sections. Designation of respondent (Owner/Manager/staff), Type of stakeholder (Main, sub Management), capability of university Status in terms of finances), availability of International Students (Yes/No), Level of internationalization attained (respondent perception), Legal and intellectual immigration barriers in internationalization of universities.

Data Analysis: Respondents' data and secondary research was analyzed according to sections and variables.

\section{Discussion}

Structural Change Adaptation of Universities
The higher education sector has played a vital role in the internationalization of the national universities with desired structural changes adaptation and entering into the race of global knowledge economy. In these contexts various socio economic changes were witnessed in various regions of the world and particularly in South-East Asia. Monk [1] has the view that in Vietnam and main land of China some deregulation activities at the Government level were observed for more growth in industrial commodities export and various policies of health, transport, communication and education were changed for internationalization.

\section{Evolution of International Education Market}

Most of the universities are looking inclined towards internationalization of their academic \& research programs in the competitive international knowledge based economic market and selling their competencies/higher education services in different regions of the world. Currently the universities in Asian Region are also indulged in the race to win and make profit are evolving as business corporations. In south Asian Region most of the universities has their major agenda to capture international students market of Middle East and Africa. Tin [2] has emphasized the trend of students' induction success stories and quoted that courtiers like Singapore, Taiwan and Japan appeared on leads besides India, Pakistan and Malaysia.

As mentioned by Talik [3] that the internationalization of universities even in the developed countries like UK and USA, the trend of state funding was declined and most of the universities diverted towards Marketization and converged to business hubs in the knowledge based economic benefits streams and managed their economic resources through internationalization of research programs and selling of academic programs with international students intake. He pleaded that in higher education systems, the state funding has a unique value for national economic development of the country.

\section{Assessment of Universities Internationalization}

Elkin [4] has the generalized view that in a country, the university internationalization could be assessed with the following parameters;

- The nationally practiced academic programs standardization for according to the international focused programs.

- Links developed with international institutions.

- Launch of international students exchange programs.

- Undertake internationally recognized research activities.

- Undertake international students support programs.

- International Research collaboration programs.

- Attendance to International conferences, seminars \& exhibitions.

- Faculty and staff exchange programs.

International Students Recruitment 
The Cudmore [5] reported that by the year 2025, the number of international student at world level shall be about 07 million which will be a positive sign of good earning of the universities and achieving internationalization of higher education globally. He emphasized such projection on the study of various institutions of Canada, USA and UK. He further deliberated the reasons why international students prefer to be enrolled in the universities of Canada, Australia, USA and UK, the only reason is of lacerative market, value of the institution and successful cultural diversity.

\section{Trend of internationalization of universities}

The trend of internationalization of universities especially for the recruitment of international students was not declined due to 9/11 disaster / terrorism attacks on USA. Jacobson [6] and Walker [7] discussed the trend of students' induction and quoted that the students' induction was not affected rather a continual increase of students' intake was carried out in USA universities from China, India and South Korea. They have further emphasized and indicated that about $25 \%$ decrease of students intake was observed from Muslim states like Pakistan, Saudi Arabia, Malaysia, and Kuwait \& United Arab Emirates (UAE). From these countries the interest of International students' recruitment was diverted towards universities of Canada, Australia and New Zealand being alternative source of USA universities has transpired that international students' recruitment was not only considered for internationalization of institutions but also to generate revenue by charging high fee from the applicants for coping with issues of lack of state funding.

Edward. J [8] has also emphasized that in most of the countries, higher education institutions and universities are adopting American model of internationalization of academic and research programs and attraction of international researchers that caused brain drain in different regions. The English proficiency requirements were made a standard for students' enrolment. The American institutions are playing as prominent actor in internationalization process and appearing as role model especially for developing countries that creating greater impact towards international cooperative research and educational exchange partnerships.

\section{Immigration policies}

The Immigration policies of the countries also affect International students Induction programs. The countries who in real sense support their higher educational institutions for their internationalization and developing research linkages and students recruitment might relax immigration rules and regulations and encourage the international students, researcher/teachers recruitment from the international market.

The Third world countries now inspired to cater for skill and technological advancements to meet international standards. This can only be achieved through development of educated work force in the institutions that may develop linkages in the learned universities of the developed world and to achieve minimum requirements of their academic excellence. While in the way of such growth in these countries like Pakistan the trend of commercialization of international student recruitment creating a negative impact on the developing world.

\section{Ranking \& International Students}

The existing of international students seems to be a integral part of international ranking of the university. Hazelkorn E [9] quoted the examples of Australia, Germany and Japan and stressed that the international students play important role as weapon in the battle of talent. In Australia 2 universities are in top 100 universities Shanghai Jiao Tong Academic Ranking of World universities or 8 in the Times QS Ranking of world universities 2007 and Germany had 6 or 3 and Japan had 6 or 4 respectively.

Likewise, in Pakistan as per Higher Education Commission of Pakistan (HEC) ranking as per details mentioned in the Annual Report [10], the COMSATS Institute of Information Technology, Pakistan is at No. 4 amongst 136 Pakistani general universities exists in both public and private sectors.

\section{International Students Comparison of Some Pakistani Universities}

The International Islamic University (IIU) is at the top position in respect of international students' recruitment in Pakistan. There are 1726 international students belongs to 40 different countries. The National University of Science and Technology (NUST) has only 11 international students and in Bahria University there are only 14, while the COMSATS Institute of Information Technology (CIIT) Pakistan enrolled 21 International students including 5 in Masters programs during the year 2012-13. The CIIT is inspiring and strengthening international linkages and has planned to induct at least 250 international students in next 03 years, besides collaborative agreement with more than 100 international universities of the world including USA, UK and Germany.

\section{Major source of induction}

The major source of induction of international students for the European universities was Asia but now in Asia most of the universities in the region have attained excellence in research and academics and indulged in the race of internationalization of their programs for better earning and creating cross cultural environment. The view point of Galway [11] shows three reasons to recruit international students; the opportunity to generate revenue, mix up of foreign prospective $\&$ culture to local perspective traditions for creating multicultural environment and thirdly to enhance institutional international knowledge business economic trade links like contractual \& sponsored joint ventures and projects.

As per quotes in the Annual Report [12], in Pakistan CIIT is focusing to recruit international students from member states of Organization of Islamic Cooperation (OIC) and Commission on Science and Technology on Sustainable Development in the South (COMSATS) under various scholarship schemes and allocated more than 200 
scholarships at Masters level in high-tech areas like Physics, Computer Science, Mathematics, Meteorology, Health informatics and Biosciences.

\section{Trend of Pakistani Universities towards Internationalization}

Study in Pakistan Expo was held the year 2012 and total 44 Pakistani Universities \& Institutions participated in Expo at Ajman UAE, while another Expo was held again in March 2013 wherein the number of participating Pakistani universities was 39. During the past few years the trend of internationalization was increased in Pakistani universities in spite of intense cultural issues and adoptability. In the CIIT model, the humanitarian aspect for internationalization is very prominent in view the reason that this Institute specially offered 260 Masters level scholarships to the international students but the aspect of corporatization and business earning with higher fee charging cannot be ignored like other universities of the world.

\section{Results}

In the World especially, in South East Asian region some deregulations and structural changes in universities were undertaken and such changes also expanded in Middle East, Africa and Pakistan and diverted towards internationalization to generate own funding resources by inducting international students with high fee structure. The adoption of knowledge based economic systems has been adhered on the role models practiced in USA, UK, Australia and Canada in the last 2 decades. In Pakistani university, especially CIIT Pakistan is moving on faster track towards internationalization and inspired for induction of international students in future with more leadership commitment on academic and research collaboration with international universities and organizations.

\section{Conclusions}

The global trend of internationalization of universities now diverging towards corporatization is evident and most of the international universities especially in Asia, South East Asia are adopting the policies for revamping of their structures, methodologies and trends as according to the role models of USA Canada and UK universities. The universities are also diverging towards contractual research, joint ventures of academic research \& projects, including by efforts made by the individual academicians. In Pakistan the CIIT is aggressively moving towards internationalization in view of manifold advancement in scholars exchange programs, faculty and staff training all over the world under HRD programs and with the help Government funded projects. The global humanitarian higher education aspect of CIIT is positioning it in future and emerging like a major player of higher educational service provider and then its steady conversion to corporatization in Pakistan.

\section{Recommendations}

a) Further primary and secondary research is need to undertaken to assess exact position of Pakistani universities with particular reference to CIIT Pakistan and their participation and efforts towards internationalization, international ranking and corporatization.

b) Futuristic Study for internationalization of CIIT Pakistan to be conducted by the researchers on the basis of existing successful role models of developed countries like USA, Germany, UK, Canada and Australia. In Asia the comparison with role model of Malaysia.

\section{REFERENCES}

[1] Monk. K. H. Questioning for Internationalization of Universities in East Asia-Critical Reflection. International Symposium at OSAKA University Japan. 2006 January 13-14.

[2] Tin. Z.P. Academic Exchange and Educational Modernization, Hangzhou Zhejiang University Press. 2005.

[3] Talik. J.B.G. Global Trend in Funding Higher Education. Marketization and Economic Themes. 2006 winter; (42)

[4] Elkin. Visualization of Internationalization of Universities. International Journal of EducationalManagement .2007;19(4) :318-229

[5] Cudmore G. Globalization, Internationalization and the Recruitment of International Students in Higher Education, and in the Ontario College of Applied Arts and Technology, The Canadian Journal of Higher Education, 2005; 35(1): 37-60.

[6] Jacobson J. Foreign Students Enrolment Strategies, New Security Measures Lead to Decline Among Muslim Countries. Chronicle of Higher Education. 2003.

[7] Walker. P. Buying in and selling out, Quality Issues in International Students Contracting Agreements. Quality in Higher Education 1999; 5 (3).

[8] Edward J. Challenges and opportunities in Higher Education in Coming Decades, Planed and Opportunistic Initiatives in American Institutions. Journal of Studies of International Education 2007; (11): 373.

[9] Hazelkorn E. Globalization, Internationalization and Ranking. International Higher Education, Internationalization. Dublin Institute of Technology. 2007; 8-11.

[10] Annual Report Higher Education Commission, Pakistan. www.hec.gov.pk. 2011-12

[11] Galway A.D. Going Global, Ontario College of Arts and Technology. International Students Recruitment and the Export of Education. University of Toronto. 2007.

[12] Annual Report. COMSATS Institute of Information Technology Pakistan. www.comsats.edu.pk. 2012-13. 